\author{
Tomasz P. Górski \\ Wyższa Szkoła Bankowa we Wrocławiu \\ togorski@wp.pl
}

\title{
BOLESŁAW LEŚMIAN JAKO TŁUMACZ
}

DOI: http://dx.doi.org/10.12775/RP.2018.004

\begin{abstract}
Zarys treści: Bolesław Leśmian znany jest przede wszystkim jako poeta, dramaturg i krytyk, natomiast jego twórczość przekładowa rzadko bywa przedmiotem badań. Artykuł stanowi rozpoznanie Leśmiana jako tłumacza i - pośrednio - jego związków z literaturami obcymi. Na podstawie zachowanych utworów zgromadzonych w Dziełach wszystkich i innych istotnych materiałów źródłowych szkicuje jego poglądy na sztukę przekładu, wskazuje na zachowane tłumaczenia (opowiadania Poego oraz baśnie orientalne), sugerując sposoby ich badania, oraz na zainteresowanie Leśmiana tekstami i autorami, których tłumaczył lub chciał tłumaczyć. Efektów tej pracy przekładowej nie znamy i z tego względu artykuł pokazuje kierunek i cel poszukiwań tych materiałów. W końcowej części zaprezentowane są propozycje badawcze przekładów poety oraz możliwości włączenia tłumaczeń do analizy całego dzieła Leśmiana.
\end{abstract}

Słowa kluczowe: Bolesław Leśmian, przekład, nieznane przekłady Leśmiana

\section{Wstęp}

Z ainteresowanie badaczy postacią i twórczością Bolesława Leśmiana w ostatnich latach zdaje się wzrastać, co widoczne jest w postaci licznych publikacji analizujących biografię poety, jego poglądy poetyckie, związki twórczości z autorami polskimi i obcymi, a także w studiach poświęconych rozmaitym komparatystycznym i literaturoznawczym afiliacjom. Aktywność przekładowa autora Łaki traktowana jest w nich niestety marginalnie i - poza kilkoma pracami (głównie autorstwa Żanety Nalewajk) - nie została, jak dotąd, dogłębnie zbadana. Niniejszy artykuł skupi się na analizie tego zagadnienia; ze względu na ograniczenie formalne i szczątkowy wręcz materiał badawczy będzie miał charakter zarysu, a problemat winien rozwinąć się w postaci szczegółowych analiz i obserwacji. 


\section{Wokół Dzieł wszystkich}

Niestrudzony leśmianolog Jacek Trznadel podjął się edycji dzieł zebranych poety, które Państwowy Instytut Wydawniczy wydawał w latach 2010-2012. W 2016 r. uzupełnione zostały one o Kalendarium leśmianowskie, również w opracowaniu Trznadla, dzięki czemu dysponujemy obecnie pełnym zbiorem utworów tego autora, włączając $\mathrm{w}$ to materiały, których oryginały przechowuje Biblioteka Uniwersytetu w Austin. Trznadel jednak ostrożnie używa określenia „zebrane”. Jest świadomy, że spenetrowano wiele archiwów, przeprowadzono wiele kwerend bibliotecznych w Polsce i za granicą, lecz istnieje jeszcze przynajmniej kilka tropów poszukiwań i miejsc, do których nie udało się dotrzeć, a które być może zawierają spuściznę literacką Leśmiana lub też materiały biograficzne. Nie zbadano znajdującego się w Argentynie archiwum po żonie poety i jego córce (nie wiadomo nawet, czy wciąż istnieje), nie znamy losów francuskiej biblioteki poety; „nie ma, nie wiadomo, nie odnaleziono" - takie określenia przytacza Trznadel (2016: 7) jako odpowiedzi na prośby o możliwość dalszych poszukiwań. Dzieła wszystkie są zatem zbiorem znanych, odnalezionych i dostępnych pod różną postacią tekstów, co jednak nie wyklucza dalszych odkryć.

Badanie dzieła Leśmiana jest zadaniem jednocześnie łatwym i trudnym. Łatwość polega na analizie dostępnych materiałów, zarówno w postaci tekstów literackich, jak i biograficznych, które są obecnie zamkniętym korpusem. Trudność z kolei wynika z faktu, że dane te są niekompletne, stosunkowo niewielkie i nierzadko pełne sprzeczności: informacje pochodzące od rodziny (żony poety, jego córki Marii Ludwiki Mazurowej i Jana Brzechwy) często mijają się ze stanem faktycznym, jawią się jako wybiórcze, relacje świadków epoki i ówczesnego środowiska Kijowa, Iłży, Hrubieszowa, również Warszawy są rozbieżne, plotkarskie, a nawet wzajemnie się wykluczające. Wiele dokumentów spłonęło podczas wojny, część listów Leśmiana do Teodory Lebenthal została zniszczona, nie znamy żadnej korespondencji do poety, choć wiadomo, że pisywał z wydawcami w Polsce, tłumaczami jego tekstów na języki obce (np. na czeski) oraz z literatami z Rosji. To wszystko sprawia, że mimo monumentalnego przedsięwzięcia Trznadla Leśmian i jego dzieło są znane w formie niekompletnej.

Zastanawiający jest ponadto fakt, że w związku z brakiem materiałów źródłowych wielu badaczy przyjmuje założenie mówiące o porzuceniu przez Leśmiana pomysłu ukończenia, a nawet rozpoczęcia pracy nad pewnymi tekstami. Szczególnie dotyczy to pracy tłumaczeniowej. „Przekład De Costera 
jakoś nie doszedł do skutku" - pisze Nina Taylor (2000: 279), opierając się na braku informacji o tym zadaniu w korespondencji poety, poza wzmianką, w której Leśmian pisze o swoim zamówieniu od Mortkowicza. Nie znamy tego przekładu (szerzej o tym niżej), lecz nie oznacza to bynajmniej, że wcale on nie powstał. Wydaje się, że warto uznać go raczej za nieodnaleziony, podobnie zresztą jak wiele innych utworów, o których w dostępnych dokumentach wspomina autor Dziejby leśnej.

\section{Poglądy Leśmiana na sztukę przekładu}

W analizie tego problemu znów, o czym napisano wyżej, dużą rolę odgrywają archiwalia. Nie znamy żadnych prac poety traktujących ściśle o przekładzie. Wiadomo natomiast, choćby na podstawie przekładów z Poego, że Leśmian zajmował się praktyką tłumaczeniową; recenzował ponadto przekłady na język polski i rosyjski. Skąpość materiałów nie pozwala na przedstawienie tego zagadnienia w sposób pełny i kompleksowy, lecz mimo to można wymienić przynajmniej kilka obserwacji dających wgląd w to zagadnienie. Pochodzą one $\mathrm{z}$ publikowanych przez poetę recenzji.

1. Każda $\mathrm{z}$ recenzji jest komentarzem Leśmiana do przetłumaczonego dzieła. Zawierają one opis akcji (czas, miejsce, niekiedy streszczenie utworu), pewne informacje o autorze i oryginale (jedynie w przypadku Ptaka niebieskiego Maeterlincka jest wzmianka o pierwowzorze rosyjskim tego tekstu, a następnie jego wersji francuskiej; por. $D z W s z 3^{1}$ : 133).

2. Recenzje nie zawierają analizy porównawczej oryginału $z$ tłumaczeniem. Co prawda Leśmian odnosi się do języka oryginału, lecz są to raczej ogólne konstatacje, a nie studia przypadku: „Tłumacz starał się oddać suchość i bladość samego oryginału, którego język daleki jest od pełnego napomknień i niespodzianek dawnych arcydzieł Maeterlincka" (DzWsz3: 136-137), bądź

Przekład p. Antoniego Langego oddaje jak zazwyczaj wszelkie odcienie i nastroje tych utworów pradawnych. Poeta nasz, przekładając, odbywa, zda się, wielką podróż duchową po krainach zamierzchłych i duchem swoim obcuje z duchami ludów minionych (DzWsz3: 424-425),

${ }^{1}$ DzWsz3 jest odsyłaczem do 3 tomu Dzieł wszystkich Leśmiana, pod red. J. Trznadla, zawierającego szkice literackie, $D z W s z 4$ - do listów zamieszczonych w tomie 4 . Pełny adres zob. wykaz literatury. 
a także „P. Witwicki w doskonałym przekładzie zachował całą złotolitość oryginału i oddał nawet czarodziejska prostotę i naiwność składni greckiej” (DzWsz3: 473).

3. Poeta stawia, szczególnie w przypadku przekładów przeznaczonych dla teatru, wysokie wymagania estetyczne: „Repertuar [...] przekładowy, winien w każdym razie stać na najwyższym poziomie wymagań artyzmu" (DzWsz3: 195).

4. Tłumacza widzi jako poetę, który wpływa na rozwój literatury języka przekładu i wzbogaca ją o nowe formy wyrazu:

E. Porębowicz [...] jest więcej niż przekładcą: jest poetą, który raz jeszcze wyśpiewał pieśni, ongi śpiewane. Przekładami swymi autor wnosi do poezji polskiej tony nowe oraz język ku owym tonom zdążający i odrębny w swym toku wewnętrznym, pomimo iż język ten jest wzorowany i zaczerpnięty z pieśni ludowej polskiej. (DzWsz3: 429)

Po raz to pierwszy w naszej literaturze, o ile pamiętam, zjawia się wiersz o rymach nie końcowych, lecz niespodzianych, w miejscu, gdzie same słowa poza wymogami strofy rymują się nagle, jak gdyby w celu potajemnego zwrócenia na siebie rozpierzchłej kiedyś uwagi i baczności. (DzWsz3: 486)

5. Poeta zwraca uwagę na kształt poetycki tłumaczenia, jego organizację poetycką i wersologiczną oraz na warstwę leksykalną:

A. Lange przełożył [Ramayanę - T.P.G.] wierszem kunsztownym, już to dosłownie, już też w transpozycji dowolnej, zgodnie wszakże z duchem samego poematu. Poeta próbował w przekładach wierszowanych rozmaitych form i rytmów, tak iż księga ta będzie odtąd źródłem pomysłów i skarbnicą wzorów dla przyszłych tłumaczów Ramayany [...]. (DzWsz3: 349)

Przekłady Balmonta pełnią się czarem, pozyskanym w drodze zapatrzenia się w ducha oryginału i zasłuchania się w rytm i ton języka. Dla ciągłego przypomnienia tego rytmu i tonu Balmont misternie okrasza swój przekład słowami jednako brzmiącymi w obydwu językach. (DzWsz3: 492)

6. Skupia się na odbiorze przekładu i określając wartości estetyczne, mówi o porównywalnym, a nawet identycznym efekcie, który wywiera on na czytelnika w języku oryginału i przekładu: 
[Przekłady Bronisławy Ostrowskiej - T.P.G.] nie robią [...] wrażenia przekładów, nie zastanawiają uwagi naszej pokonaniem większych lub mniejszych trudności, nie niepokoją domysłów naszych artystycznych dążeniem lub niedosiężeniem istniejących poza nimi pierwowzorów. Czytamy je tak samo, jak spowiedź własną poetki [...]. (DzWsz3: 486)

Dodaje również, że tomik Ostrowskiej „to [...] zbiór utworów ulubieńszych, które, oczarowawszy tłumaczkę, łatwiej i jakby samochcąc zrzuciły swą szatę francuską, ażeby się odtąd stać utworami polskimi” (DzWsz3: 486).

7. Leśmian ocenia przekład przez pryzmat jego znaczenia dla kultury i życia duchowego:

Staff [tłumacz Kwiatków św. Franciszka z Asyżu - T.P.G.], przekładając tę księgę przedziwną, obdarzył literaturę naszą relikwią, której czas i świętość, i genialność, winny wzruszać każdego, co się dłonią i duszą kart tej księgi dotyka. Przekład P. Staffa jest więcej niż zwykłym przekładem: jest owocem trudów „miłości wielkiej”, jest „wyrazem jego głębokiego podziwu, wzruszenia i serdecznej wdzięczności”. (DzWsz3: 466)

8. Pokazuje wpływ tłumacza na przełożony utwór; wskazuje na inspiracje kierujące jego wyborem tekstu i na związek przekładów z twórczością poetycką tłumacza:

Poetka [Bronisława Ostrowska - T.P.G.] w wyborze utworów kierowała się nie tym, które z nich najlepiej charakteryzują twórczość danego autora, lecz tym, które z nich najbardziej spokrewnione są z jej własną duszą. Jest to więc zbiór utworów najulubieńszych [...]. Uzupełniają one twórczość oryginalną p. Bronisławy Ostrowskiej. Wyśpiewując je raz jeszcze w języku ojczystym, nie pozbywa się poetka tonów własnych, tłumiąc je tylko i głusząc, a raczej biorąc z tonów obcych tę tylko cząstkę i ten tylko zamiar, który nie wzbrania jej słowom toczyć się tak samo swobodnie, jak w utworach własnych. (DzWsz3: 486)

9. Przetłumaczony na język polski utwór traktuje Leśmian jako wzbogacenie literatury polskiej, jako dzieło „przyswojone”. Widać to w recenzji Staffowskich Kwiatków..., a także w dyskusji na temat przekładów Henryka Heinego przedstawionych przez Władysława Nawrockiego: „Tłumacz podjął się tej pracy w celu wzbogacenia naszej literatury utworami genialnego poety, którego ton czarował wielu twórców naszych" (DzWsz3: 489). Nie jest jednak w tym stanowisku konsekwent- 
ny. Analizując przekład Ise-Monogatari na język polski, pisze już jedynie o możliwości wglądu polskiego czytelnika w specyfikę oryginału, która to możliwość wynika z zamiany wiersza na prozę i odmienności (dźwiękowej) języków japońskiego i polskiego:

Przekłady przytoczonych fragmentów nie mogą czytelnikom naszym dać dokładnego wyobrażenia o powieści japońskiej, której głównym czarem i urokiem są wiersze, osnute na obcych językom europejskim środkach dźwiękowych. Przetłumaczyliśmy te wiersze prozą, a przecież wiemy o tym, że wiersz tłumaczony prozą przestaje być wierszem - przestaje być poezją. Musimy tylko domyślać się ich śpiewnego uroku - ich napomknieniowego czaru, związanego ściśle z nagłym i niespodzianym zestawieniem wyrazów. (DzWsz3: 519)

10. Od tłumacza Leśmian oczekuje kompetencji językowej i znajomości realiów oryginału: O Balmoncie - tłumaczu utworów Słowackiego na rosyjski - pisze:

Kierowany chęcią dokładnego poznania literatury polskiej, zdobył znajomość języka, która mu pozwoliła zajrzeć w samą głąb twórczości naszej i pod niejednym względem spokrewnia się z nami nastrojach i tonach, mających źródło wspólne prasłowiańskie. [...] W każdym słowie Balmonta czuć erudycję i znawstwo naszych przeżyć literackich (DzWsz3: 490-491),

a o tłumaczeniu Ise-Monogatari: „Tłumacz - (N. Konrad) wyposażył swój przekład w dwie niezwykłe, ciekawe przedmowy i w bogate przypisy, z których czerpiemy swoje wiadomości” (DzWsz3: 512).

Jak się jawi, w kontekście powyższych obserwacji, Leśmian jako znawca przekładu i jakie miał poglądy na sztukę translatorską? Wydaje się, że nie jest to wiedza obszerna. Brak w przytoczonych fragmentach specjalistycznej terminologii, odwołań do tekstów teoretycznych, wskazówek dla tłumaczy i krytycznej refleksji opartej na wnikliwym porównaniu oryginału z przekładem, poeta w żaden sposób nie odnosi się do rozróżnienia między „przekładem” a „spolszczeniem”. Poza powszechnie znanym, dyskusyjnym i szeroko komentowanym poglądem o tłumaczeniu wiersza na prozę nie pisze Leśmian o przekładzie jako o twórczości, którą sam uprawiał, a przecież wszystkie przytoczone recenzje ukazały się po publikacji jego tłumaczeń z Poego. Być może jest to spowodowane formą wypowiedzi - recenzją - w której poeta uznał zamieszczanie takich informacji za bezzasadne. Mimo to wyłania się z poglądów Leśmiana pewna interesująca perspektywa, pewien istotny punkt 
widzenia. Przetłumaczony tekst analizuje recenzent jako twór przynależny do literatury polskiej (ten problem rozwinęła wiele lat później Stefania Skwarczyńska (1975), a następnie Itamar Even-Zohar w teorii wielosystemowej. $Z$ tej perspektywy Leśmianowska ocena przekładu jest próbą oglądu języka, wartości estetycznych z punktu widzenia polskiego odbiorcy. Ten odbiorca czyta przekład, ponieważ nie zna języka oryginału (być może pobrzmiewa już tutaj „iluzja czytania oryginału” proponowana przez Lewickiego - 1993: 10), recenzję traktuje jako zachętę do sięgnięcia po lekturę i nie oczekuje od niej precyzyjnych analiz przekładowych i komparatystycznych.

Warto zwrócić uwagę na jeszcze jedną istotną kwestię, która rzuca pewne światło na tłumaczeniową (i recenzencką) kompetencję Leśmiana. Chodzi o znajomość języków obcych. Biegle władał on rosyjskim, mógł zatem przekłady Balmonta ocenić niezwykle rzeczowo. Miał możliwość porównania przekładów Ostrowskiej z oryginałami, gdyż znał również francuski. Uczył się greki, lecz nie była to znajomość pozwalająca na konfrontację przekładu $\mathrm{z}$ oryginałem Uczty Platona. Nie znał natomiast niemieckiego, angielskiego ani japońskiego, więc w kontekście publikowanych recenzji przekładów z tych języków staje się Leśmian krytykiem tych tekstów w języku polskim i - jako poeta - patrzy na nie okiem literata. Ten literacki filtr jest zresztą charakterystyczny dla wszystkich recenzji tłumaczeń, to istotny wyznacznik zawartości merytorycznej Leśmianowskich tekstów i może tłumaczyć pominięcie w nich zagadnień przekładu.

\section{Motywy tłumaczenia}

Zainteresowanie autora Sadu rozstajnego przekładem (ściślej - praktyką przekładu) wynika z różnych pobudek, które dzielą się na dwie grupy, przy czym nie można wykluczyć, że w nierzadko łączą się one w wielowątkowe motywy zacierające granice między jedną i drugą.

Pierwszym powodem były względy zarobkowe. Leśmian, borykający się często z problemami finansowymi, otrzymywał wynagrodzenie za swoje utwory oryginalne (np. o honorarium od Mortkowicza za Pieśni przelotne pisze w liście z 1912 r. do Z. Przesmyckiego, DzWsz4: 382-383), toteż podejmował się tłumaczeń również dla pieniędzy. Opowieści nadzwyczajne to zbiór przekładów, który poeta wykonał na prośbę przyszłego wydawcy Jana Lorentowicza (por. list Leśmiana do Miriama z 1912 r. - DzWsz4: 385). Mimo utyskiwania na wysokość zapłaty („honorarium [od Mortkowicza - T.P.G.] dane właściwie dla opędzenia się od autora i dla załatwienia formalności” 
- list do Z. Przesmyckiego z roku 1912 r., DzWsz4: 383) był gotowy do kolejnych działań: „To pewna, że dane mi pieniądze na marne nie pójdą i mogę co chwila składać dowody pracy bezwzględnie nieustannej" (list do Z. Przesmyckiego z roku 1912, DzWsz4: 383). Nie można wykluczyć, że recenzje (przekładów i nowych utworów literatów polskich) pisał również z pobudek finansowych.

Drugi powód zajęcia się tłumaczeniem to inspiracje Leśmiana twórcami obcojęzycznymi. Fascynacja literaturą rosyjską (m.in. Gogolem, Puszkinem), prywatne i listowne kontakty z literatami ówczesnej Rosji (małżeństwem Mierieżkowskich, Balmontem, Briusowem, Łosiewem, Fetem), literaturą francuską i francuskojęzyczną (Baudelaire’em, Rimbaudem, Verlaine’em, Maeterlinckiem), filozofią francuską (przede wszystkim Bergsonem) oraz Poem (którego twórczość poznał dzięki przekładom Baudelaire’a) - wszystkie stanowiły dla poety natchnienie, impuls twórczy, wzór do naśladowania. W wywiadzie udzielonym Edwardowi Boyé w 1934 r. (DzWsz3: 545) otwarcie przyznaje się do wpływu, jaki wywarł na niego autor Kwiatów zła; mówi też o Poem, zastrzegając jednocześnie, że „tych wpływów nie widać jakos" $(D z W s z 3: 545)^{2}$. Lektura pisarzy obcych wywoływała u Leśmiana twórczy potencjał, przynosiła nowe pomysły, popychała go do kolejnych odkryć literackich i mobilizowała do pracy:

[T] e dwa tomy [Opowieści nadzwyczajnych - T.P.G.] wcale mnie nie określają i nie zaspokajają tego, co się we mnie dzieje. Czuję w sobie dużo rozmaitych pierwiastków i możliwości. Słowem, chce mi się przynajmniej kilka pomysłów wykonać. (list do Z. Przesmyckiego z roku 1912, DzWsz4: 383)

Leśmianowskie inspiracje niełatwo oddzielić w tym wypadku od kwestii finansowych. Jego euforia i chęć do działania miała bowiem również podłoże materialne i trudno ocenić, $\mathrm{w}$ jakim stopniu radość pisania była efektem urzeczywistniania pomysłów literackich, a w jakim możliwością zarobku. Oba impulsy - pisarski i zarobkowy - traktowane osobno lub oddzielnie, należy wziąć pod uwagę jako czynniki wpływające na powstanie Leśmianowskich przekładów.

${ }^{2}$ Mimo tego zastrzeżenia literaturoznawcy poświęcili wiele miejsca, dowodząc, że Poe w znacznym stopniu ukształtował Leśmianowską poetykę i stał się dla polskiego poety ważną inspiracją (por. m.in. Głowiński 1984). 


\section{Przekłady Leśmiana}

Dorobek przekładowy Leśmiana należy ograniczyć, bez względu na motywy i inspiracje, do dwóch języków: rosyjskiego i francuskiego. Znał poeta oba, mógł więc teksty czytać w oryginale. W jego listach i szkicach literackich często pojawiają się nazwiska twórców, których tłumaczy lub których chciałby tłumaczyć, jednak większości tych przekładów nie znamy. Być może nigdy nie powstały (takie założenie przyjmuje znaczna część badaczy), być może zaginęły, być może istniały tylko w rękopisie, być może są to przechowywane $\mathrm{w}$ archiwach manuskrypty anonimowe lub podpisane pseudonimem, wreszcie - może opublikowane w czasopismach pod pseudonimem, których atrybucja jest nieznana lub niepewna. Poniżej, śledząc korespondencję poety, jego kalendarium i inne prace, przedstawiony zostanie względnie kompletny zbiór twórców obcojęzycznych, którymi Leśmian zainteresował się w kontekście przekładu.

1. Stone (1976: 6) podaje, że Leśmian dla zabawy przekładał rosyjską poezję nonsensu. Było to jeszcze w czasach kijowskich i są to być może najstarsze (pierwsze?) próbki tłumaczeń. Badaczka prawdopodobnie ma na myśli „bezsensowny wierszyk”, który poeta przetłumaczył dla żartu razem z Brzechwą. Brzechwa cytuje ów przekład w tekście wspomnieniowym Niebieski wycieruch (1966: 110):

Wczesnym rankiem, wieczorkiem

Wśród nocy, o świcie

Jechała baba wierzchem

w szerokiej karecie

A za nią pędem

Wolnymi kroczkami

Wilk starał się przepłynąć

Miskę z jagodami.

Nie znamy niestety rosyjskiego oryginału tego utworu.

2. W liście do Miriama z 1897 r. poeta zapowiada możliwość wydania utworów Antoniego Langego, m.in. Sielanki, Na roli i Posagu i dziewczyny w tłumaczeniu rosyjskim (DzWsz4: 284). Trznadel (2016: 40) sugeruje, że mogą być to przekłady Leśmiana. Brak innych informacji na ten temat.

3. Tłumacz o nierozpoznanych inicjałach N.M. (być może Leśmian) w 1900 r. w Kijowie ogłasza przekład Jasia uzdrowionego (Исиеленный 
$\left.Я_{c b}\right)$. Autora oryginału przedstawia tłumacz jako „krajana-kijowianina”, „młodego polskiego poetę, który zdążył zwrócić uwagę swoimi utworami" (por. Kaźmierczak 2010: 283).

4. W dwóch listach do Miriama z r. 1901 (?) i z r. 1903 (DzWsz4: 311) mowa jest o przekładzie Ibsena. Leśmian informuje swojego patrona o posiadaniu tekstu dramaturga po niemiecku i po francusku, które następnie zwrócił do „Chimery”. Dodaje: „Do przekładu Ibsena przystąpię dopiero po powrocie z Kijowa” (DzWsz4: 307). Ani nie znamy zapowiadanego tłumaczenia, ani nie wiemy, jaki utwór (utwory?) zamierzał przekładać.

5. Leśmian informuje listownie Z. Przesmyckiego, że ze względów materialnych oddał swój tekst do druku w „Sztuce”. Rymkiewicz (2001: 279-280) wysuwa dwie hipotezy: mógł być to przekład poematu Flandria Verhaerena lub Filozofia umeblowania i Willa Landor Poego. Flandria została podpisana inicjałem J.R, przekłady z Poego są niesygnowane.

6. Poeta (znów w liście do Miriama z lutego lub z marca 1906 r.) myśli o pozostaniu w Paryżu i poświęceniu się tłumaczeniu literatury francuskiej na polski dla Mortkowicza. Zamierza przekładać m.in. Mallarmégo i Rimbauda (DzWsz4: 364). Rzeczonych przekładów nie znamy.

7. Kolejne nieodnalezione tłumaczenie. Leśmian przesyła Miriamowi przekład Verlaine’a (list z 1907 r., DzWsz4: 370). Być może jest to Skrzypiec jesieni, przekład Chanson d'automne z tomu Poèmes saturniens z roku 1866. Zachowała się ostatnia zwrotka tego tekstu $\mathrm{w}$ przekładzie Leśmiana (cytowana z pamięci przez Brzechwę; por. Brzechwa 1966: 87):

$\begin{array}{ll}\text { Et je m’en vais } & \text { I wicher zły } \\ \text { Au vent mauvais } & \text { Gna mnie przez mgły } \\ \text { Qui m’emporte } & \text { Swoim podmuchem, } \\ \text { Deçà, delà, } & \text { To wprzód, to wspak } \\ \text { Pareil à la } & \text { Miota mną jak } \\ \text { Feuille morte } & \text { Źdźbłem suchem }\end{array}$

8. Z Paryża, prawdopodobnie w grudniu 1911 r., w liście do Miriama Leśmian donosi o przyjęciu zamówień od Mortkowicza: „Bajki arabskie, książka oryginalna dla dzieci i przekład De Costera” (DzWsz4: 374). Pierwsze to Klechdy sezamowe (wyd. 1913) lub Przygody Sind- 
bada Żeglarza (rok 1913 lub 1914), być może też chodziło o bajki orientalne („arabskie”), które rozrosły się do dwóch tomów, a książką dla dzieci są wydane później Klechdy polskie. Oba teksty, osadzone w folklorze Dalekiego Wschodu, przykuwają uwagę badaczy jako pozycje dla dzieci, a Przygody Sindbada... przynależą „do kategorii zwykłych rzemieślniczych robót translatorskich" (Grodzki 2012: 21). Warto podkreślić „translatorskich”, gdyż rzadko traktuje się je jako efekt pracy tłumacza ${ }^{3}$. Podczas pracy nad Przygodami... i Klechdami... Leśmian korzystał przynajmniej z trzech wersji Księgi tysiąca i jednej nocy $\mathrm{w}$ przekładach na polski, francuski i rosyjski: z polskiego tłumaczenia niemieckiej przeróbki Grimma Powieści z tysiąca i jednej nocy. Dla młodzieży z 1893 r.; francuskiego przekładu Mardrusa Le Livre des Mille et une nuit (1908-1911) i z polskiego tłumaczenia Gallanda (wyd. w r. 1898 i 1900). Tak skomplikowany pierwowzór powoduje, że niełatwo jest ustalić, jak przebiegała praca nad tym tekstem, które (i w jakim stopniu) fragmenty pierwowzoru weszły do tekstu polskiego, jak Leśmian transformował swój oryginał i czym się kierował, przedstawiając siedem opowieści pochodzących z Księgi tysiąca i jednej nocy. Trudności te zdaniem Grodzkiego (2012: 20) skutecznie odstraszały badaczy, a problem Przygód... jako przekładu i jego pierwowzorów, jak dotąd, nie został dokładnie rozpoznany.

Drugie zamówienie to przekład De Costera, lecz nie znamy tego tekstu. Najprawdopodobniej dotyczyło ono przekładu słynnych przygód Dyla Sowizdrzała, czyli La Légende et les Aventures hérö̈ques, joyeuses et glorieuses d'Ulenspiegel et de Lamme Goedzak au pays de Flandres et ailleurs z 1867 r. (pierwsze polskie tłumaczenie Juliana Rogozińskiego ukazało się w 1914 r.)

${ }^{3}$ Grodzki (2012: 26) pisze, że Przygody... nie są przekładem, lecz rodzajem adaptacji zwanym transformacją. Pogląd swój opiera na teorii baśni i w tej perspektywie jego rozumowanie jest poprawne. Jeśli natomiast zastosować do Przygód... aparat przekładoznawczy, to również można je określić jako pewien typ adaptacji, gdyż jest ona także strategią translatorską (por. Dąmbska-Prokop 2000: 27-30). Z kolei dla Newmarka (1988: 46) „adaptacja” to jeden Z najmniej ograniczonych („the freest”) typów tłumaczenia, stosowany głównie w tekstach literackich. W Encyklopedii... pod redakcją Baker i Saldanhy (2011: 3-5) odnośne hasło wskazuje na adaptację jako formę przekładu stosowaną w tłumaczeniu dla dzieci. Dodatkowo procedury wykorzystywane w adaptacji to m.in.: dosłowne tłumaczenie pewnych partii tekstu oryginalnego, pominięcie lub poszerzenie niektórych fragmentów oryginału, zamiana oryginału na przekład, który zawiera jedynie najważniejsze informacje/idee/funkcje oryginału (Baker, Saldanha 2011: 3-5). Wszystkie te cechy można odnieść do Przygód Sindbada... Termin „adaptacja” w teorii baśni i w teorii przekładu wydaje się funkcjonować na bardzo podobnych, jeśli nie identycznych zasadach. 
bądź Légendes flamandes (wyd. 1858 r.) lub Contes Barbanconnes (1861). Przekład ten rzeczywiście mógł nie zostać wykonany, gdyż praca nad baśniami arabskimi przeciągała się, ponadto Leśmian musiał już wówczas pisać Klechdy polskie i wiersze włączone potem do tomu Sad rozstajny, a także Skrzypka opętanego; brak jednak tutaj zupełnej pewności.

9. Rok 1912 - cztery tropy tłumaczeniowe. Pierwszy: tłumaczenia Szewczenki. Zdaniem Łopuszańskiego (2000: 106) utwory te powstały, lecz nie zostały wydrukowane, ponieważ Leśmian „przeładował je własnym stylem i neologizmami”. Drugi - w tym samym roku (1912) rosyjskie czasopismo „Аполлон” (nr 5, s. 60) zamieszcza informację o przygotowywanym przez Leśmiana przekładzie wierszy Balmonta i o szkicach krytycznych o twórczości rosyjskiego poety. Trzeci trop: w liście do Żeromskiego Leśmian prosi autora Popiołów o pomoc w publikacji wyboru przekładów w jednym bądź dwóch tomach utworów Sałtykowa-Szczedrina w „Książce” (DzWsz4: 389-391). Czwarty - ukazuje się w tym czasie w Polskiej literaturze wspótczesnej wzmianka Potockiego o Leśmianie: „Tłumacz znakomity Verhaerena, Pawła Forta i innych poetów francuskich" (por. Trznadel 2016: 121). Tłumaczeń Szewczenki, Balmonta i Szczedrina, ani też poetów francuskich, nie odnaleziono.

10. W 1913 r. poeta pracuje nad zamówionym przez Lorentowicza przekładem z Poego, które z końcem tegoż roku ukazuje się wraz z Leśmianowskim słowem wstępnym, w dwóch tomach, pod tytułem Opowieści nadzwyczajne. Podstawą przekładu utworów Amerykanina jest francuskie tłumaczenie Baudelaire’a (wybór dwudziestu nowel z dwutomowej edycji Histoires extraordinaires i Nouvelles histoires extraordinaires), podobnie jak Słowo wstępne będące przekładem eseju Edgar Poe. Sa vie et ses œuvres, który to esej Leśmian skraca, streszcza w nim nie zawsze zgodne z prawdą informacje biograficzne o Poem, kalkuje podniosły styl, imituje składnię, dąży do zachowania oryginalnego szyku wyrazów i spolszcza nazwy własne. Właściwie poza pracami Nalewajk ${ }^{4}$, która konfrontuje Leśmiana z Baudelaire'em i Poem, nie mamy praktycznie żadnych kompleksowych opracowań tego tłumaczeniowego problematu twórczości Bolesława.

${ }^{4}$ Autorka omawia te zagadnienia w licznych artykułach publikowanych na łamach wielu czasopism, najpełniejszy jednak ogląd zawarła w pracy Leśmian międzynarodowy - relacje kontekstowe. Studia komparatystyczne (Nalewajk 2015). 
11. Pisze Leśmian w liście z 26 grudnia 1921 r. do przebywającej wówczas we Francji Lebenthal:

Może uda Ci się dostać od kilku autorów (słynniejszych) francuskich lub cudzoziemskich (o ile przebywają w Paryżu) pozwolenie piśmienne na przekład polski, może od Romain Rollanda, Anatola France’a, Benoit, prócz tego wyszła tam słynna powieść jakiegoś Murzyna, nazywa się René Maran, tytuł Batouala [...]. (DzWsz4: 416)

Nie jest to czas szczególnie płodny literacko dla poety, można zatem przypuszczać, że pracował już nad tymi przekładami, a z pewnością czytał w oryginale trzech pierwszych twórców. Nie wiemy, czy Lebenthal spełniła prośbę; nie znamy także tych tłumaczeń.

12. Leśmian jest autorem dwóch rosyjskich cykli poetyckich: Лунное похмелье (10 wierszy; pierwodruk w Moskwie w 1907 r. w periodyku „Весы”), Волны Живые (2 wiersze; „Перевал”, Moskwa 1907) oraz pięcioczęściowego utworu Песни Василисы Премудрой, opublikowanego w czasopiśmie „Золотое Руно” w Moskwie w 1906 r. Wszystkie, w oryginale i w przekładach na polski, weszły do Dzieł... Nie odnaleziono do dziś rosyjskojęzycznego dramatu Leśmiana pt. Василий Буслаев, choć wiemy, że istniał, gdyż wspomina o nim Maksym Gorki (por. Kaźmierczak 2010: 282). W kontekście tej twórczości pojawia się nawet określenie Leśmiana jako poety dwujęzycznego (por. m.in. Migal 2010: 204). Nie odniósł on jednak sukcesu jako poeta rosyjskojęzyczny. Wasyłenko (2002: 139) tłumaczy to zbyt późnym „ujawnieniem” jego talentu czytelnikom i literaturoznawcom (dopiero pod koniec lat 50. XX wieku). Niedostatecznie duże zainteresowanie tymi utworami w Rosji sprawiło, że Leśmian mógł zrezygnować z rosyjskiego na rzecz polskiego. Czy oznacza to, że rzeczywiście zupełnie przestał pisać po rosyjsku? Publikował przecież na łamach trzech najbardziej znanych, prekursorskich ówcześnie czasopism symbolistycznych - literackim parnasie. Tego nie wiemy. Nie potrafimy również odpowiedzieć na pytanie, czy Leśmian, nierozpoznany w Rosji, nie przetłumaczył swoich wierszy na polski, próbując zaistnieć jako poeta polski. Nie można jednak wykluczyć, że nie był to wyłącznie rosyjskojęzyczny epizod i że autotłumaczenia powstały, choć ich nie znamy. 


\section{Zakończenie}

Mimo wydania Dzieł wszystkich Leśmiana twórczość przekładowa poety zajmuje marginalną pozycję w stosunku do oryginalnej. Znamy obecnie, ogólnie rzecz ujmując, jedynie dwa wykonane przez niego przekłady - Opowieści nadzwyczajne i cykl orientalny (Klechdy sezamowe oraz Przygody Sindbada Żeglarza) - a to niewiele, jeśli weźmiemy pod uwagę jego zainteresowania literaturami obcymi, chęci (nieurzeczywistnione?) przekładania wybranych pisarzy czy też wykonane tłumaczenia (Szewczenki, Verlaine’a). Być może ta skąpość materiału wywołuje niewielkie zainteresowanie badaczy Leśmianem jako tłumaczem. W tekstach krytycznych poety znajdujemy jedynie zdawkowe uwagi na temat przekładu i trudno na ich podstawie formułować uogólnienia. Jeśli jednak przyjmiemy, że - jak pisał w recenzji Ostrowskiej twórczość własna tłumacza ujawnia się również w wykonanym przez niego przekładzie oraz że przekłady na polski należą do literatury polskiej, to daje to pewien wgląd w pojmowanie przez niego tej sztuki. I nawet jeśli te uwagi nie są odkrywcze w XXI wieku, to sformułowanie ich 100 lat wcześniej zdaje się świadczyć o ich ówczesnej aktualności. Może w Leśmianie tłumaczu trzeba zobaczyć zalążek myśli przekładoznawczej, która została eksplicytnie wyartykułowana dopiero ponad pół wieku później, może Leśmian tłumacz to kontynuator już wcześniej sformułowanej poetyki przekładu? A jeszcze jak tłumaczył Leśmian? Czy był zwolennikiem metody „tekstowej” czy „rekonstrukcyjnej”, w opinii Drzewieckiej (1971) znamiennych dla przekładów tego okresu? Czy i w jakim stopniu działalność przekładowa wpływała na twórczość Leśmiana po polsku? Można również zadać pytanie odwrotne: jaki jest związek i wpływ utworów polskich poety na jego poetykę przekładu? Takie białe plamy można mnożyć. Na rozstrzygnięcie tych zagadnień, a także na udzielenie odpowiedzi na wiele innych pytań trzeba poczekać do czasu ujawnienia opisanych wyżej tekstów.

Leśmianologia bez analizy tłumaczeń nie jest nauką o kompleksowej naturze. Nie jest również leśmianologia kompletna bez przekładów poety. Jeśli przekładów nie ma, nie oznacza to bynajmniej, że nie istnieją w ogóle. „Brak czegoś - to jeszcze nie dowód na nieistnienie tego czegoś" (Wasyłenko 2002: 141). Obiecujące wydają się przynajmniej dwa kierunki: archiwa i muzea rosyjskie (do dziś z różnych powodów nieprzeszukane) oraz książnice polskie (teksty anonimowe, pisane pod pseudonimami). Ciągle nie zbadano piwnicy budynku w Warszawie przy Rakowieckiej, gdzie w czasie wojny żona i córka Leśmiana ukryły rękopisy poety. Wiemy natomiast, jakich tekstów szukać 
i co mogą one ujawnić, a to - przynajmniej obecnie - ciekawa i korzystna perspektywa.

\section{Literatura}

Baker, M., Saldanha, G. (red.), 2011, Routledge Encyclopedia of Translation Studies, London, s. 3-7.

Brzechwa, J., 1966, „Niebieski wycieruch”, [w:] Wspomnienia o Bolesławie Leśmianie, J. Jastrzębski (red.), Lublin, s. 79-104.

Dąmbska-Prokop, U. (red.), 2000, Mała encyklopedia przekładoznawstwa, Częstochowa, s. 27-30.

Drzewiecka, A., 1971, Z zagadnień techniki tłumaczenia poezji. Studia nad polskimi przekładami liryki francuskiej $w$ antologiach $z$ lat 1899-1911, Kraków.

Głowiński, M., 1984, „Leśmian, Poe, Baudelaire”, [w:] Wielojęzyczność literatury i problemy przekładu artystycznego, E. Balcerzan (red.), Warszawa, s. $157-169$.

Grodzki, B., 2012, Leśmianowska baśń nowoczesna. O „Przygodach Sindbada Żeglarza" Bolesława Leśmiana, Lublin.

Kaźmierczak, M., 2010, „Leśmian po rosyjsku - zarys recepcji”, [w:] Literatura polska wświecie. Obecności, t. 3, R. Cudak (red.), Katowice, s. 281-292.

Leśmian, B., 2010-2012, Dzieła wszystkie, J. Trznadel (red.), t. 1: Poezje zebrane, t. 2: Szkice literackie, t. 3: Baśnie i inne utwory proza, t. 4: Utwory dramatyczne. Listy, Warszawa.

Lewicki, R., 1993, Obcość w odbiorze przekładu, Lublin.

Łopuszański, P., 2000, Bolesław Leśmian, Wrocław.

Migal, I., 2010, „Leśmiana w język rosyjski wyprawa”, [w:] Teksty Drugie, nr 6 (126), s. 195-210.

Nalewajk, Ż., 2015, Leśmian międzynarodowy - relacje kontekstowe. Studia komparatystyczne, Kraków.

Newmark, P., 1988, Approaches to Translation, Hertfordshire.

Rymkiewicz, J.M., 2001, Leśmian. Encyklopedia, Warszawa.

Skwarczyńska, S., 1975, „Przekład i jego miejsce w literaturze i kulturze narodowej (Na przykładzie Hamleta w wersji Józefa Paszkowskiego)", [w:] eadem, Pomiędzy historia a teoria literatury, Warszawa, s. 187-221.

Stone, R., 1976, Bolesław Leśmian. The Poet and His Poetry, Berkeley - Los Angeles - London.

Taylor, N., 2000, „Klechdy polskie - baśń nieustająca”, [w:] Twórczość Bolesła- 
wa Leśmiana: studia i szkice, T. Cieślak, B. Stelmaszczyk (red.), Kraków, s. $275-293$.

Trznadel, J., 2016, Kalendarium leśmianowskie. Życie i twórczość w układzie chronologicznym, Warszawa.

Wasyłenko, W., 2002, „W kręgu rosyjskojęzycznej poezji Bolesława Leśmiana", tłum. H. Owsiany, [w:] Poetyki Leśmiana. Leśmian i inni, E. Czaplejewicz, W. Sadowski (red.), Warszawa, s. 139-161.

\section{Bolesław Leśmian as a translator}

\section{Summary}

Bolesław Leśmian is primarily known as a poet, a dramatist and a critic, while his translations are rarely the subject of academic research. The article offers an insight into Leśmian's output as a translator and, indirectly, into his connections with literatures in foreign languages. As based on the available pieces included into his Collected Works and other relevant source materials, the paper outlines Leśmian's views on the art of translation, indicates his existing translations (Poe's stories and Arabian tales), thus suggesting the modes of their analysis, as well as his interest in texts and authors that he translated or wanted to translate. Since the outcomes of many of his endeavours are unknown, the paper indicates the directions and aims of further investigations. In its final part, translation research proposals and some of the possibilities of including these translations in the analysis of Leśmian's works are presented.

Keywords: Bolesław Leśmian, translations, Leśmian’s unknown translations

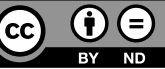

